Research Article

\title{
Geotechnical Properties of Wood Ash-Based Composite Fine-Grained Soil
}

\author{
Bayshakhi Deb Nath ${ }^{D},{ }^{1}$ Grytan Sarkar, ${ }^{1}$ Sumi Siddiqua, ${ }^{2}$ Md. Rokunuzzaman, \\ and Md. Rafiqul Islam ${ }^{1}$ \\ ${ }^{1}$ Department of Civil Engineering, Khulna University of Engineering \& Technology, Khulna 9203, Bangladesh \\ ${ }^{2}$ School of Engineering, The University of British Columbia, 3333 University Way, Kelowna, BC, CanadaV1V 1V7 \\ Correspondence should be addressed to Bayshakhi Deb Nath; bayshakhidebnath@yahoo.com
}

Received 11 August 2017; Accepted 25 March 2018; Published 8 April 2018

Academic Editor: Arnaud Perrot

Copyright ( $\odot 2018$ Bayshakhi Deb Nath et al. This is an open access article distributed under the Creative Commons Attribution License, which permits unrestricted use, distribution, and reproduction in any medium, provided the original work is properly cited.

\begin{abstract}
It is observed in Bangladesh that there is an extensive use of wood as a solid biomass for heat and electricity production, which led to increase in the amount of combustion residues known as ash. These ashes are discarded and dumped here and there, resulting in pollution of the environment. It could be managed by using wood ash as a stabilizer of soft clay. It is found that there is an enhancement of the engineering properties of existing soil in stabilized forms particularly unconfined compressive strength (UCS), shear strength parameters, workability, and compaction and compressibility characteristics. Therefore, laboratory tests associated with these properties were performed for some selected percentage of wood ash, for example, $0 \%, 5 \%, 7.5 \%, 10 \%$, and $12.5 \%$. Chemical investigation of wood ash depicts that it contains approximately $30 \% \mathrm{CaO}$, which directs it to behave like a pozzolanic material. Besides, the test result signifying that the soil could be made lighter with the increase of moisture content, strength, and reduction of compressibility due to the addition of ash content.
\end{abstract}

\section{Introduction}

During the last decades, some construction difficulties of foundation resting on soft clay have been observed. These soils are treated as problematic soils as they have high compressibility and low shear strength. They also may have a tendency to swell and shrink. One of the indications for the soft soil is undrained shear strength smaller than $40 \mathrm{kPa}$ [1]. These soils pose higher strength at dry state and lose their strength when there is an increase in moisture content. These types of dispersive soils are also highly prone to erosion [2]. Therefore, these soils are not fit for the construction of infrastructure on them as they have a high risk of settlement. Moreover, the available land for construction is very limited. Hence, it has become a challenging task for a foundation engineer to design and construct a foundation on such soft soil. There are different methods practiced to improve the engineering properties of such soils such as stabilization, grouting, removal and replacement, removal and recompaction, preloading, vibroflotation, stone columns, and dynamic compaction and reinforcement using geosynthetics [3-8]. These methods improve the physical and chemical properties of soil in such a way that the soil becomes consistent; hence, the strength is increased and deformability and permeability are reduced. Although compaction and consolidation methods work very well for granular soil, it takes a long time for the soil to consolidate (months to years) especially with the cohesive soil [9]. Moreover, in the case of highly organic soft soil, it is not possible to improve the geotechnical properties of soil with these methods. Replacement methods could be the possible solution for organic soil, where the organic soil to a sufficient depth is replaced with granular soil such as sand and crushed stones or preloading to improve engineering properties [10]. Chemical stabilization is an alternative low-cost solution, where stabilizing agents such as cement, lime, fly ash, and other binders stabilize the organic soil rapidly through chemical reactions [11-13]. 


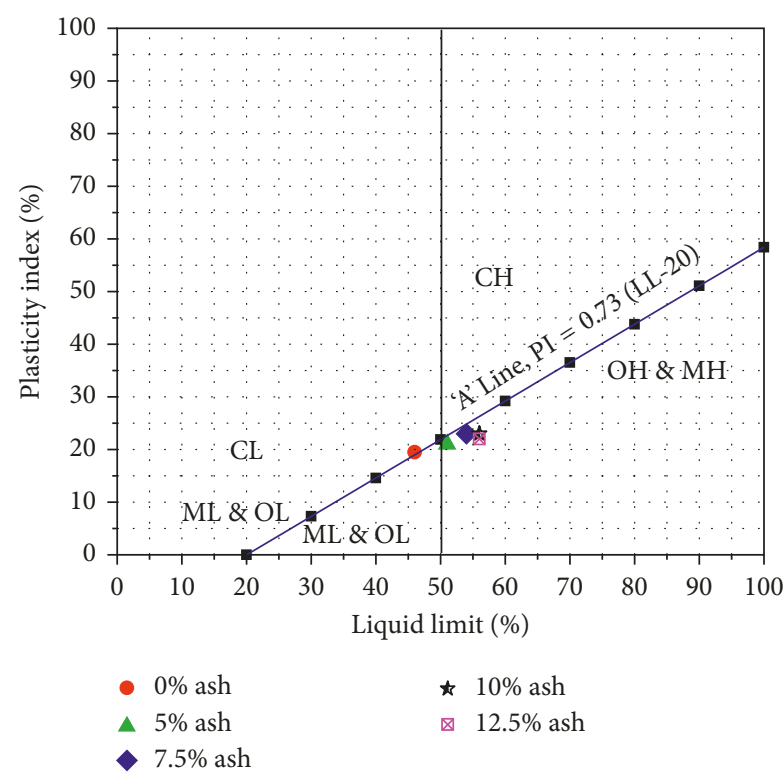

FIgURE 1: Plasticity chart showing the original and wood ashtreated soil.

Soil stabilization using chemical additives such as cement, rice husk ash (RHA), fly ash, and lime is widely used because of their cementitious constituents [14-18]. These cementitious constituents modify and stabilize soft soil through cation exchange, flocculation and agglomeration, and reactions [19]. However, the selection of chemical additives depends on several factors such as dry density, shear strength [20, 21], workability (in surficial improvement techniques), and durability [22]. Barends [23] categorized soil improvement techniques for soft soil according to the manner of treating the soil.

Wood that is widely used as a fuel and energy sources has led to a strong increase in the amount of combustion residue. Wood ash is a gray material produced from the combustion of wood. It is generally discarded as waste and dumped outside of house or landfill, which increase the volume of landfill. A country like Bangladesh, where population density is very high, needs to manage this waste properly in the limited landfill area. Therefore as an alternative solution, this ash can be used as a potential soil stabilizer through the chemical reaction. The chemical composition of wood ash implies that it can be used as a substitute of $\mathrm{CaO}$ (that contains about $30 \% \mathrm{CaO}$ ) for soil stabilization. It lacks plastic properties with particles that are mostly smaller than 0.075 millimeter in size. It is found from the literature that the concentration of heavy metals present in the wood ash is very low $[24,25]$. However, this ash may be leaching heavy metals into the soil, but the movement of the metal concentration is slow. The slow movement of the leachate is attributed to the reduction of solubility of the leachate due to the contribution of the $\mathrm{pH}$ value from wood ash. As long as the value of $\mathrm{pH}$ is above 6 , the metals will remain bound in the soil, chemically locked in place $[26,27]$.

Khulna is the southwest part of Bangladesh having finegrained soil with some organic deposits, which, due to the
TABle 1: Physical properties of soil.

\begin{tabular}{lc}
\hline Properties & Soil \\
\hline Liquid limit (\%) & 46 \\
Plasticity index (\%) & 19 \\
Specific gravity & 2.71 \\
OMC $(\%)$ & 22 \\
MDD $\left(\mathrm{kg} / \mathrm{m}^{3}\right)$ & 1550 \\
Undrained shear strength, $S_{\mathrm{u}}(\mathrm{kPa})$ & 30 \\
\hline
\end{tabular}

TABLE 2: Chemical composition of wood ash.

\begin{tabular}{lc}
\hline Constituents & \% in wood ash \\
\hline $\mathrm{CaO}$ & 29.80 \\
$\mathrm{MgO}$ & 5.25 \\
$\mathrm{~K}_{2} \mathrm{O}$ & 9.55 \\
$\mathrm{Fe}_{2} \mathrm{O}_{3}$ & 0.95 \\
$\mathrm{Na}_{2} \mathrm{O}$ & 7.50 \\
$\mathrm{SiO}_{2}$ & 25.8 \\
$\mathrm{Al}_{2} \mathrm{O}_{3}$ & 14.72 \\
$\mathrm{P}_{2} \mathrm{O}_{5}$ & 2.33 \\
$\mathrm{TiO}_{2}$ & 0.70 \\
$\mathrm{SO}_{3}$ & 0.70 \\
Loss on ignition, LOI & 2.70 \\
\hline
\end{tabular}

lower bearing capacity, are not good for shallow foundations [28]. In the present study, wood ash is focused as a substitution of lime $(\mathrm{CaO})$ to improve the compressibility and strength characteristics.

\section{Materials and Methods}

2.1. Materials. The soil sample was collected from KUET, Khulna, Bangladesh (758686.70 m E, $2529312.06 \mathrm{~m} \mathrm{~N}$, and elevated at $3 \mathrm{~m}$ ), in a disturbed state, by manual excavation. It was then dried and pulverized using a manual hammer. The pulverized soil was sieved through a sieve of $4.75 \mathrm{~mm}$ aperture. The soil could be classified as A-7-6 and is CL (clay with low plasticity) according to the AASHTO and Unified Soil Classification System (USCS), respectively (Figure 1). The physical properties of soil are summarized in Table 1.

Wood flour was collected from the locally available sawmill and was simply burned to prepare ash. In this arrangement, pulverized wood was kept in a steel box of $1.5 \mathrm{~m} \times 1.5 \mathrm{~m}$ in dimensions. Five thermocouples with a connecting data logger were used for measuring the burning temperature. Briquettes were used as fuel to start and maintain the fire. The wood ash contained about $30 \% \mathrm{CaO}$, which is the key factor for improving soil properties (Table 2).

2.2. Methodology. Soils and wood ashes were kept in an oven at $105^{\circ} \mathrm{C}$ overnight to remove moisture and repress microbial activity. The pulverized soil and ash contents were mixed manually in a large tray in a dry state with proper care because there is a possibility of nonuniform mixing according to Table 3.

To study the influence of the wood ash on the mechanical properties of the treated samples, it is crucial to maintaining consistency between the sample preparations. It was decisive 
TABLE 3: Combination scheme of soil samples.

\begin{tabular}{lccc}
\hline \multirow{2}{*}{ Sample ID } & \multicolumn{3}{c}{ Sample description } \\
& Soil $(\mathrm{gm})$ & Wood ash $(\mathrm{gm})$ & Ash content $(\%)$ \\
\hline Original soil & 6000 & - & 0 \\
W1 & 6000 & 300 & 5 \\
W2 & 6000 & 450 & 7.5 \\
W3 & 6000 & 600 & 10 \\
W4 & 6000 & 750 & 12.5 \\
\hline
\end{tabular}

that consistency among the samples could be achieved by controlling the mixing water. In this investigation, samples were prepared using their corresponding optimum moisture content $(\mathrm{OMC})$ in order to maintain the consistency. A series of laboratory test was conducted including index testing, compaction test, UCS test, direct shear test, and consolidation test on nontreated, as well as, ash-treated soils.

Before conducting the compaction test, the nontreated and ash-treated soils $(5,7.5,10 \%$, and $12.5 \%$ ash content) were mixed with water for about ten minutes by hand. After that, the mixtures were put into polyethylene bags and mixing was continued by shaking, overturning, and pressing the bag to squeeze out the air from the soil voids. A series of standard Proctor tests, specific gravity test, and Atterberg limit test on nontreated and ash-treated soils were conducted according to ASTM D 698, ASTM D854, and ASTM D-4318, respectively.

The specimen was then statically compacted in three layers inside a cylindrical split mold, which was lubricated so that each layer reached the specified dry density. The top of the first and the second layers was slightly scarified. After the molding process, the specimen was immediately extracted from the split mold. The samples were then sized as per required for different tests and placed within the plastic bags to avoid significant variations of moisture content before testing.

Unconfined compression tests have been used in most of the experimental programs to verify the effectiveness of the treated soil. The uncured unconfined compressive strength of the cylindrical specimens $(36 \mathrm{~mm}$ diameter and $71 \mathrm{~mm}$ length) was determined according to ASTM D-2166. Shear strength parameters $(c$ and $\varphi$ ) were determined by the direct shear test (ASTM D 3080) of the compacted soil specimens $(60 \mathrm{~mm}$ diameter and $25 \mathrm{~mm}$ height). The settlement characteristics of soils were determined by performing the consolidation test (ASTM D-2435) on the samples of $63.5 \mathrm{~mm}$ diameter and $25 \mathrm{~mm}$ height.

\section{Results and Discussion}

3.1. Atterberg Limit Test Result. The Atterberg limits are very important for the characterization of soil within a broad category. The variations of liquid limit and plastic limit with the varying percentages of wood ash are shown in Figure 2. The Atterberg limit results show that both the liquid limit and plastic limit increase with increasing percentages of wood ash. The liquid limit ranged from 46 to $56 \%$ and the plastic limit from 27 to $40 \%$, thus resulting in a decrease of the plasticity index values ranging from 19 to $16 \%$. Okagbue

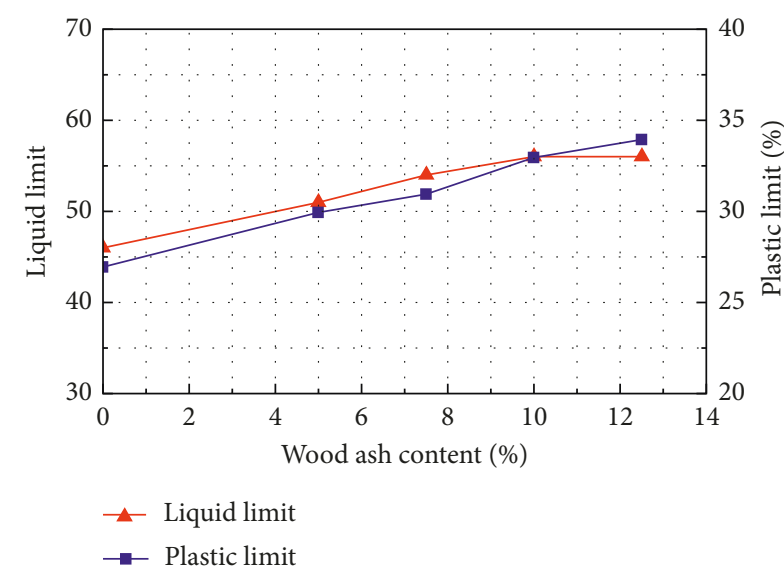

Figure 2: Variation of LL and PL with wood ash content.

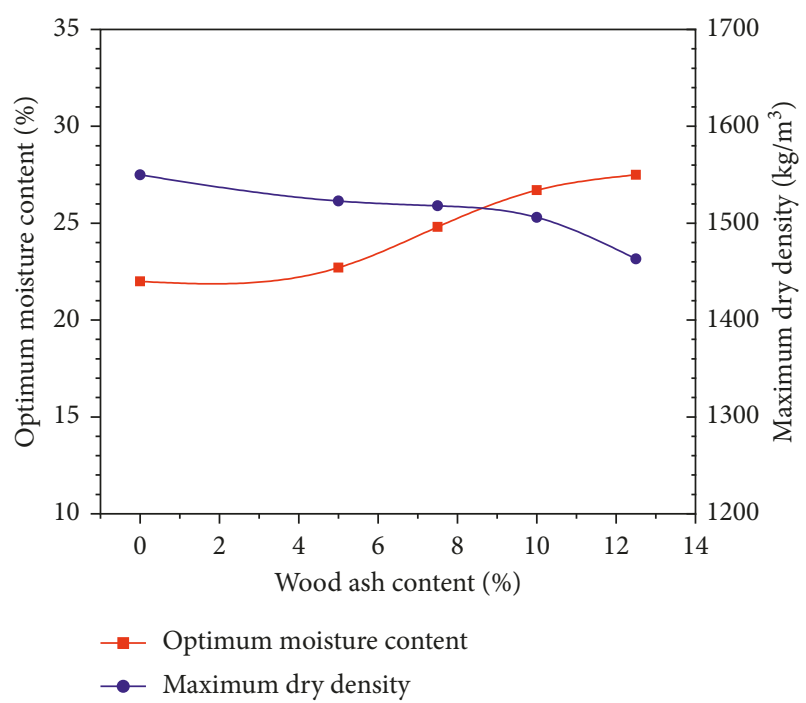

Figure 3: Variation of maximum dry density and optimum moisture content with ash content.

[29] showed the similar results and explained that these beneficial changes in engineering properties are mainly attributed to cation exchange, flocculation of the clay, agglomeration, and pozzolanic reactions. For example, rapid and immediate changes in plasticity occurred due to the cation exchange and flocculation of clay. These trends are the same as those produced when soils are treated with lime, rice husk ash, and cement [30-32].

The plasticity chart shown in Figure 1 depicts the change in form of soil grain for the addition of wood ash. This curve represents that the soil was initially containing medium plastic clay, and after being the addition of ash, it changes in form from clay to silt. This change in form is attributed to agglomeration of the clay particles due to the production of calcium silicate gel. This gel coats the clay clasts, binding them together and filling the pores, resulting in a reduction of water absorption and shrinkage as described in Okagbue [29].

3.2. Compaction Characteristics. Figure 3 shows the effect of wood ash on the optimum moisture content (OMC) and 


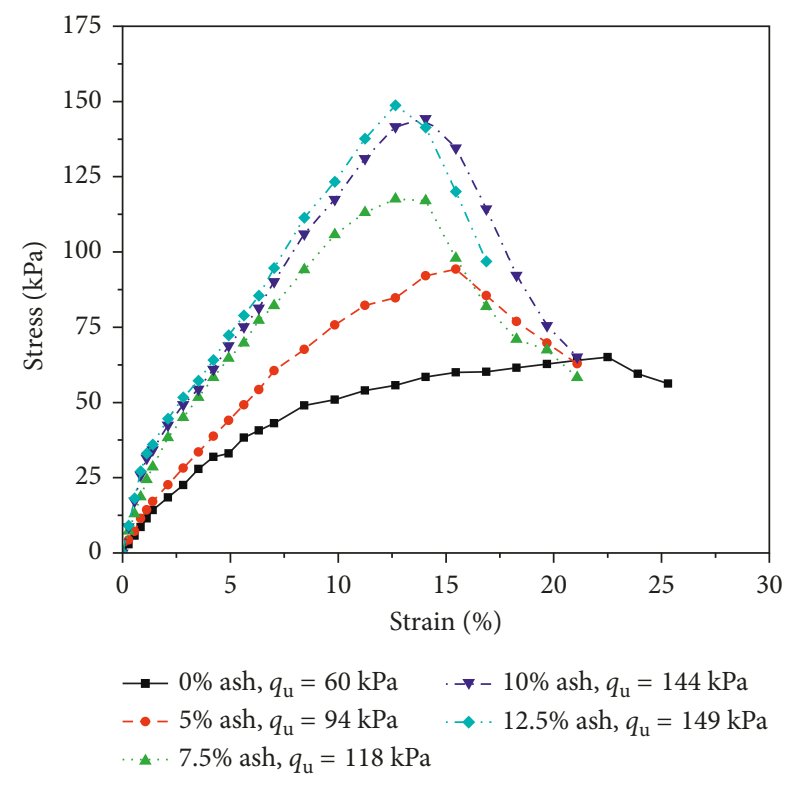

FIGURE 4: Stress-strain graphs from the UCS tests.

maximum dry density of soil. It can be seen while maximum dry density decreasing with the increasing amount of wood ash, the optimum moisture content gradually increases from $22 \%$ to $27.1 \%$ with the addition of $12.5 \%$ ash. This trend is similar with Okagbue [29], and it described that the decrease in maximum dry density is attributed by the agglomeration and flocculation of clay particles through cation exchange reaction, leading to occupy larger space as well as reducing the weight: volume ratio. This may also be due to the replacement of the relatively same volume soil particles with wood ash having lower specific gravity (1.67). For example, the specific gravity of soil is decreased from 2.71 to 2.54 after the addition of $12.5 \%$ ash content.

On the other hand, the optimum moisture content of soil increases with the increase of wood ash content as more water is required for the formation of the lime-like product, $\mathrm{Ca}(\mathrm{OH})_{2}$, and dissolution of this product into $\mathrm{Ca}^{2+}$ and $\mathrm{OH}^{-}$ ions, in order to supply more $\mathrm{Ca}^{2+}$ ions for the cation exchange reaction. Besides that the more the fines, the more the surface area, so more water is required to provide good lubrication. The ash content also decreases the quantity of free silt and clay fraction, forming coarser materials, which occupy larger spaces for retaining water.

\subsection{Strength Characteristics}

3.3.1. Unconfined Compressive Strength (UCS). For the usefulness of wood ash in improving the soil properties, unconfined compressive strength tests were conducted. Figure 4 represents graphically the stress-strain behavior of original and wood ash-treated soil under the vertical load. Initially, the stress is rapidly increasing with the increase of strain until reaching the peak value. After attaining the peak stress, it decreases with the increase of strain for both the wood ash-treated and original soils. It is also seen that the

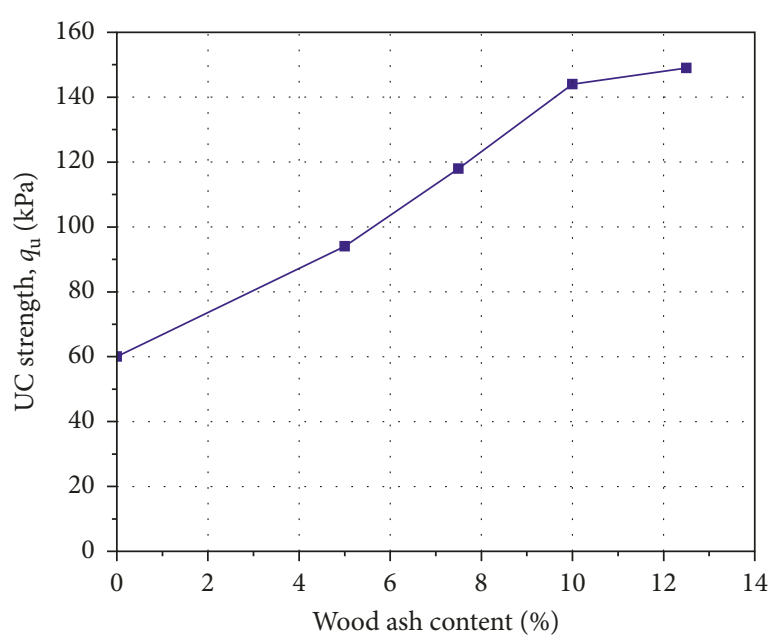

FIGURE 5: Variation of UCS with ash content.

original soil failed at a higher plastic strain compared to the wood ash-treated soil.

Figure 5 illustrates the variation of UCS with the addition of wood ash. In general, as the percentage of wood increases, the percentage of UCS increases significantly in comparison with that for untreated soil $\left(q_{\mathrm{u}}=60 \mathrm{kPa}\right)$. The illustration shows that there is a rapid increase of UCS with the addition of ash content up to $10 \%$, and for further $2.5 \%$ ash content, the UCS value is not significantly increased. Okagbue [29] also reported that $10 \%$ ash content gives the optimum value of UCS for the uncured specimens. He also estimated the UCS value for different curing days, although there is no significant improvement of strength was found. The reason for this improvement is formation cementing gels (hydrate) due to the reactions between $\mathrm{CaO}$ of ash with $\mathrm{Al}_{2} \mathrm{O}_{3}$ and $\mathrm{SiO}_{2}$ of soil. This results in agglomeration in large size particles and causes the increase in compressive strength. Therefore, wood ash can be considered as the potential additives for the stabilization of soft clay.

3.3.2. Shear Strength Parameters. The Mohr-Coulomb shear strength envelops of the original soil, and wood ash-based composite soils are shown in Figure 6. This figure illustrates that shear stress increases for every increment of normal stress, and the steepness of the curve increases with the increase of ash content up to $10 \%$. However, the curve for $12.5 \%$ ash-treated soil did not show a significant increase of steepness.

The disparity of the cohesion $(c)$ and frictional angle $(\varphi)$ with the increase of $\%$ ash content is shown in Figure 7 . It is observed that the value of cohesion gradually increases from $33.43 \mathrm{kPa}$ to $35.3 \mathrm{kPa}$ for the addition of wood ash up to $10 \%$. After that, this value suddenly drops to $34.02 \mathrm{kPa}$ for the further increment of ash content. The similar trend can be observed in the case of the angle of friction, as it rapidly increases from $18^{\circ}$ to $33^{\circ}$ up to $10 \%$ of ash content and this value decreases for the further $2.5 \%$ of wood ash content. Therefore, the optimum shear strength parameters were 


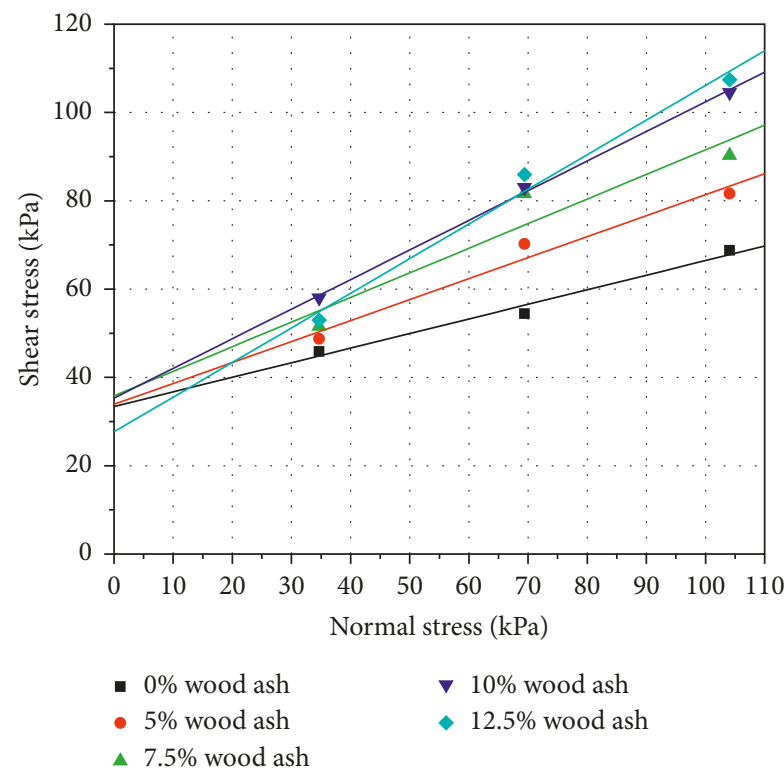

FIgUre 6: The Mohr-Coulomb failure envelops.

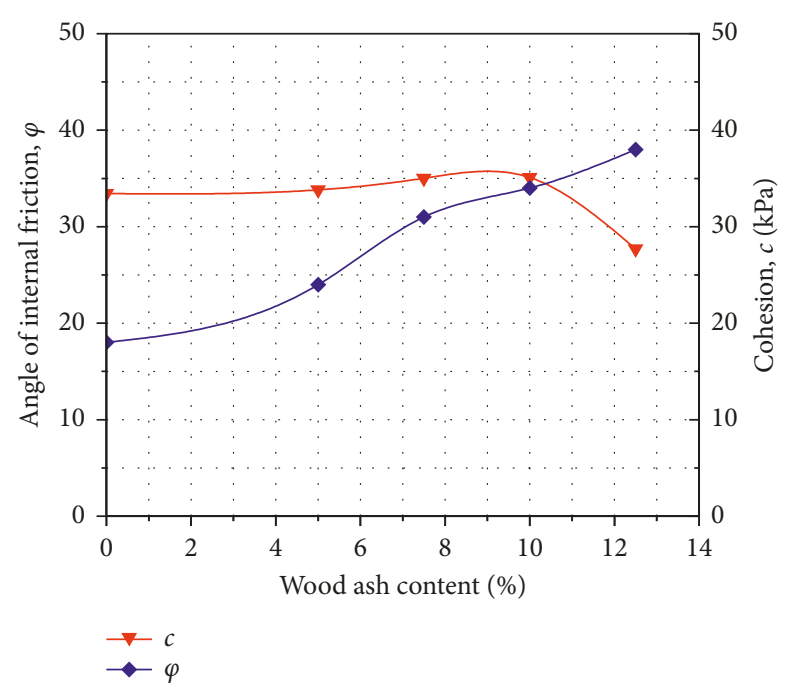

FIGURE 7: Variation of the shear strength parameters with wood ash.

found at $10 \%$ ash content, and wood ash can be a useful an additive against the shear failure of soil.

3.4. Consolidation Characteristics. The one-dimensional consolidation test was performed to determine the consolidation characteristics of both untreated and wood ashtreated soil. Figure 8 represents the relation between the void ratio and applied stress. It is seen that all the curves show a similar trend for the void ratio against applied pressure. The void ratio was found to decrease with the increase of applied pressure during the loading period, while the void ratio increases due to the release of applied pressure, but the void ratio does not get back to its original state as it undergoes plastic strain conditions.

The variation of the compression index and the initial void ratio with wood ash content is shown in Figure 9. It is

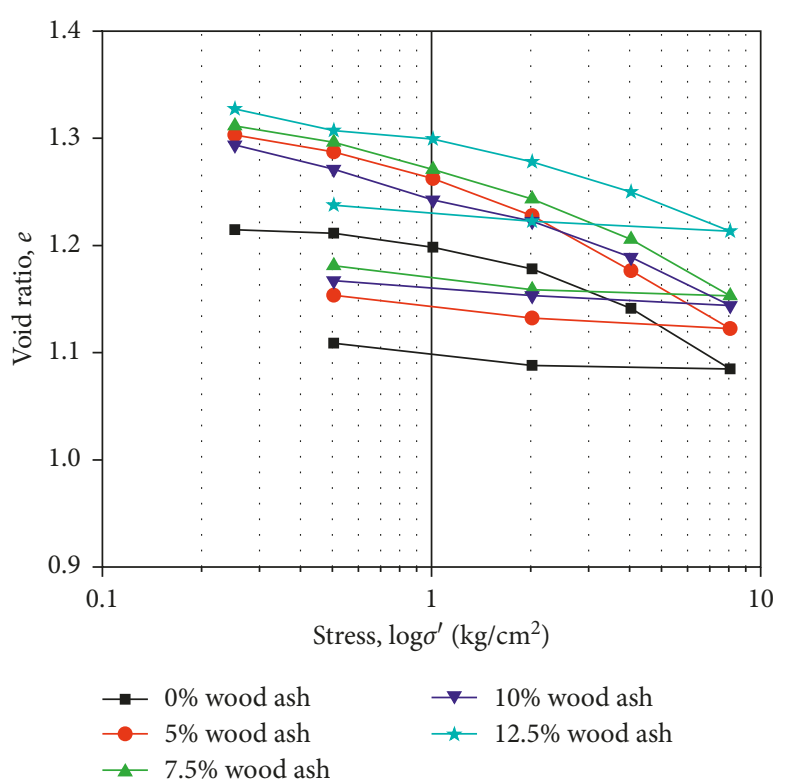

Figure 8: Plot of the void ratio, $e$, versus effective stress, $\sigma$.

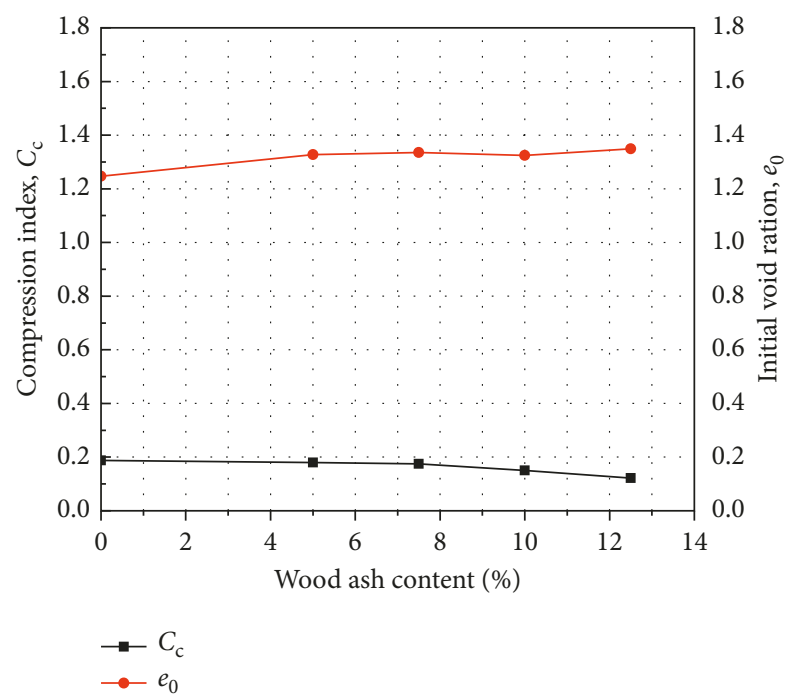

FIgURE 9: Variation of the initial void ratio $\left(e_{0}\right)$ and compression index $\left(C_{\mathrm{c}}\right)$ with ash content.

observed that the compression index $\left(C_{\mathrm{c}}\right)$ is decreasing gradually from 0.19 to 0.12 for the treatment of soil with wood ash up to $12.5 \%$. This decrease in the compression index implies that there could be a result of the increased formation of products within the pore spaces of soil from physicochemical changes which leads to a reduction in the compression index [33]. On the other hand, the value of the initial void ratio $\left(e_{0}\right)$ increased gradually for the addition of wood ash content up to $7.5 \%$, and after that, it decreases for the further amount of ash content. The decrease of the void ratio in the soil sample for the addition of wood ash content above $7.5 \%$ is attributed by the quick pozzolanic action of the soil-ash mixture. 


\section{Conclusions}

This study has evaluated the extent to which wood ash can improve the fundamental geotechnical properties such as consistency, compaction, UCS, shear strength, and settlement characteristics of untreated and wood ash-based clayey soil. The soil was stabilized through $5 \%, 7.5 \%, 10 \%$, and $12.5 \%$ wood ash content. It is observed that there is an improvement of geotechnical properties of the ash-treated soil. Based on the results obtained after completing the experimental program, the following conclusions can be drawn:

(i) Wood ash reduces the plasticity and maximum dry density of clay, while more water is required for the agglomeration and flocculation of clay particles through cation exchange reaction and coagulation with the consequent reduction in the amount of fines.

(ii) Ash stabilization causes an increase in unconfined compressive strength in the soft clayey soil, and 10\% wood ash-clay mixture optimizes the results. The larger the ash percentage inserted, the greater the strength is.

(iii) There is a sharp improvement in the shear strength parameters with the addition of wood ash. The angle of internal friction has witnessed an improvement of about $85 \%$ for $10 \%$ cement addition, while the cohesion value has an improvement of only about $6 \%$ for $10 \%$ ash addition.

(iv) From the consolidation test result, it can be concluded that the values of the compression index decreased with the increases of wood ash content and the initial void ratio increases for the ashtreated soil.

\section{Conflicts of Interest}

The authors declare that they have no conflicts of interest.

\section{References}

[1] NEN, "Identification and classification of soil-part 2: principle for a classification (ISO 14688 2:2004)," in Geotechnical Investigation and Testing, European Committee for Standardization, 2004.

[2] H. N. Ramesh and H. S. Nanda, "Strength behaviour of shedi soil treated with fly ashes," in Proceedings of the 13th ARC, pp. 893-896, New Delhi, India, September 2007.

[3] Y. Juillie and D. Sherwood, "Improvement of sabkha of the Arabian Gulf Coast," in Proceedings of the 8th European Conference on Soil Mechanics and Foundation Engineering, pp. 781-788, Helsinki, Finland, May 1983.

[4] S. Aiban, O. Al-Amoudi, I. Ahmed, and H. Al-Abdul Wahhab, "Reinforcement of a Saudi sabkha soil using geotextiles," in Proceedings of the Sixth International Conference in Geosynthetics, pp. 805-880, Atlanta, GA, USA, March 1998.

[5] O. S. B. Al-amoudi, "Characterization and chemical stabilization of Al-Qurayyah sabkha soil," Journal of Materials in Civil Engineering, vol. 14, no. 6, pp. 478-484, 2002.
[6] O. S. B. Al-amoudi, I. M. Asi, and Z. R. Ei-naggar, "Stabilization of an arid, saline sabkha soil using additives," Quarterly Journal of Engineering Geology and Hydrogeology, vol. 28, no. 4, pp. 369-379, 1995.

[7] H. Al-Abdul Wahhab, I. Ahmad, S. Aiban, and O. Al-Amoudi, "Stabilization of Al-Aziziyah (Eastern Saudi Arabia) sabkha soil," in Proceedings of the Third Conference on Roads, pp. 197-203, Sultan Qaboos University, Muscat, Oman, March 2006.

[8] I. Asi, "Stabilization of sabkha soil using foamed asphalt," Journal of Materials in Civil Engineering, vol. 13, no. 5, pp. 325-331, 2001.

[9] F. G. Bell, Engineering Treatment of Soil, E \& FN Spon, London, UK, 1993.

[10] P. Sherwood, Soil Stabilization with Cement and Lime, HMSO, London, UK, 1993.

[11] E. O. Tastan, T. B. Edil, C. H. Benson, and A. H. Aydilek, "Stabilization of organic soils with fly ash," Journal of Geotechnical and Geoenvironmental Engineering, vol. 137, no. 9, pp. 819-833, 2011.

[12] R. L. Parsons and E. Kneebone, "Field performance of fly ash stabilised subgrades," Ground Improvement, vol. 9, no. 1, pp. 33-38, 2005.

[13] S. R. Kaniraj and V. G. Havanagi, "Compressive strength of cement stabilized fly ash-soil mixtures," Cement and Concrete Research, vol. 29, no. 5, pp. 673-677, 1999.

[14] R. N. Swamy, Cement Replacement Materials. Concrete Technology and Design, Surrey University Press, London, UK, 1987.

[15] S. Sánches-Moral, S. Sergio, J. Garcia-guinea, and A. Aparicio, "Lime pozzolana mortars in Roman catacombs: composition, structures and restoration," Cement and Concrete Research, vol. 35, pp. 1555-1565, 2005.

[16] N. Latifi, A. Rashid, S. Siddiqua, and S. Horpibulsuk, "Microstructural analysis of strength development in low and high swelling clays stabilized with magnesium chloride solution-a Green soil stabilizer," Applied Clay Science, vol. 118, pp. 195-206, 2015.

[17] R. Saadeldin and S. Siddiqua, "Geotechnical characterization of a clay-cement mix," Bulletin of Engineering Geology and the Environment, vol. 72, no. 3-4, pp. 601-608, 2013.

[18] B. D. Nath, K. A. Molla, and G. Sarkar, "Study on strength behavior of organic soil stabilized with fly ash," International Scholarly Research Notices, vol. 2017, Article ID 5786541, 6 pages, 2017.

[19] L. Wang, Cementitious Stabilization of Soils in the Presence of Sulfate, Ph.D. thesis, Louisiana State University, Baton Rouge, LA, USA, 2002.

[20] B. R. Christopher, D. K. Atmatzidis, and R. J. Krizek, "Laboratory testing of chemically grouted sand," Geotechnical Testing Journal, vol. 12, no. 2, pp. 109-118, 1993.

[21] J. Warner, "Strength properties of chemically solidified soils," Journal of the Soil Mechanics and Foundations Division, vol. 98, no. 11, pp. 1163-1185, 1972.

[22] M. Kamon, C. Ying, and T. Katsumi, "Effect of acid rain on lime and cement stabilized soils," Soils and Foundations, vol. 36, no. 4, pp. 91-99, 1996.

[23] F. Barends, Introduction to Soft Soil Geotechnique, Content, Context and Application, IOS Press, Amsterdam, Netherlands, 2011.

[24] M. J. Kopecky, N. L. Meyers, and W. Wasko, "Using industrial wood ash as a soil amendment," Magnesium Research, vol. 1, no. 2, pp. 240-440, 1995.

[25] L. M. Risse and J. W. Gaskin, Best Management Practices for Wood Ash as Agricultural Soil Amendment, Bulletin 1142, University of Georgia, Athens, GA, USA, 2010. 
[26] E. Oburger, A. Jäger, A. Pasch, A. Dellantonio, K. Stampfer, and W. W. Wenzel, "Science of the total environment environmental impact assessment of wood ash utilization in forest road construction and maintenance-a field study," Science of the Total Environment, vol. 544, pp. 711-721, 2016.

[27] G. Bohrn and K. Stampfer, "Untreated wood ash as a structural stabilizing material in forest roads," Croatian Journal of Forest Engineering, vol. 35, pp. 81-90, 2001.

[28] G. Sarkar, S. Siddiqua, R. Banik, and M. Rokonuzzaman, "Prediction of soil type and standard penetration test (SPT) value in Khulna City, Bangladesh using general regression neural network," Quarterly Journal of Engineering Geology and Hydrogeology, vol. 48, no. 3-4, 2015.

[29] C. O. Okagbue, "Stabilization of clay using woodash," Journal of Materials in Civil Engineering, vol. 19, no. 1, pp. 14-18, 2007.

[30] T. H. T. Ogunribido, "Geotechnical properties of saw dust ash stabilized southwestern Nigeria lateritic soils," Environmental Research, Engineering and Management, vol. 2, no. 2, pp. 29-33, 2012.

[31] G. Sarkar, M. R. Islam, M. Alamgir, and M. Rokonuzzaman, "Study on the geotechnical properties of cement based composite fine-grained soil," International Journal of Advanced Structures and Geotechnical Engineering, vol. 1, no. 2, pp. 2319-5347, 2012.

[32] G. Sarkar, R. Islam, M. Alamgir, and M. Rokonuzzaman, "Interpretation of rice husk ash on geotechnical properties of cohesive soil," Global Journal of Research in Engineering, vol. 12, no. 2, pp. 1-7, 2012.

[33] K. J. Osinubi and A. O. Eberemu, "Effect of bagasse ash on the strength of stabilized lateritic soil," in Proceedings of the 5th Nigerian Material Congress, pp. 214-220, Abuja, Nigeria, November 2006. 


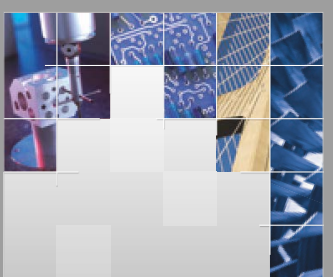

\section{Enfincering}
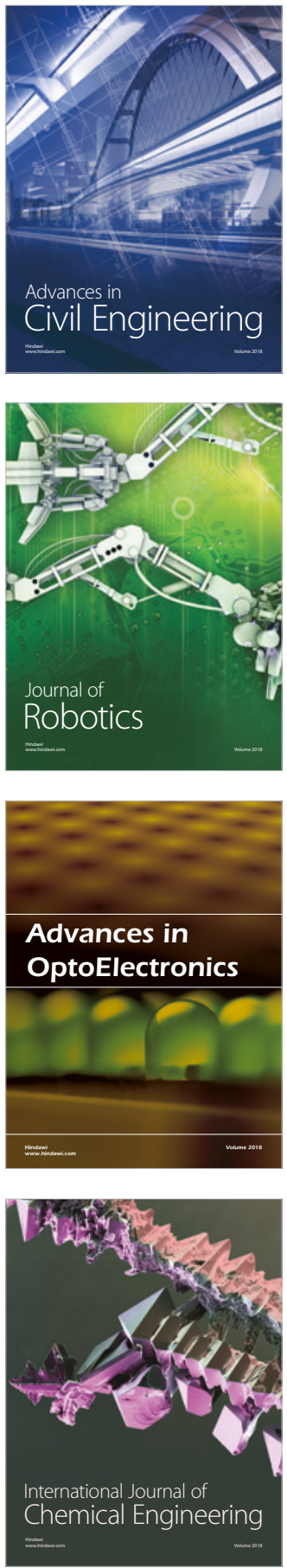

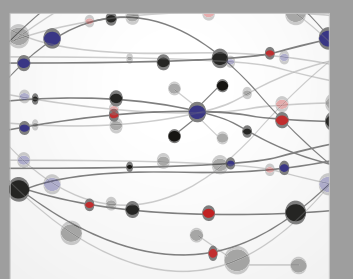

\section{Rotating \\ Machinery}

The Scientific World Journal

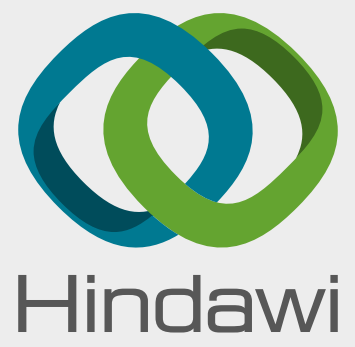

Submit your manuscripts at

www.hindawi.com
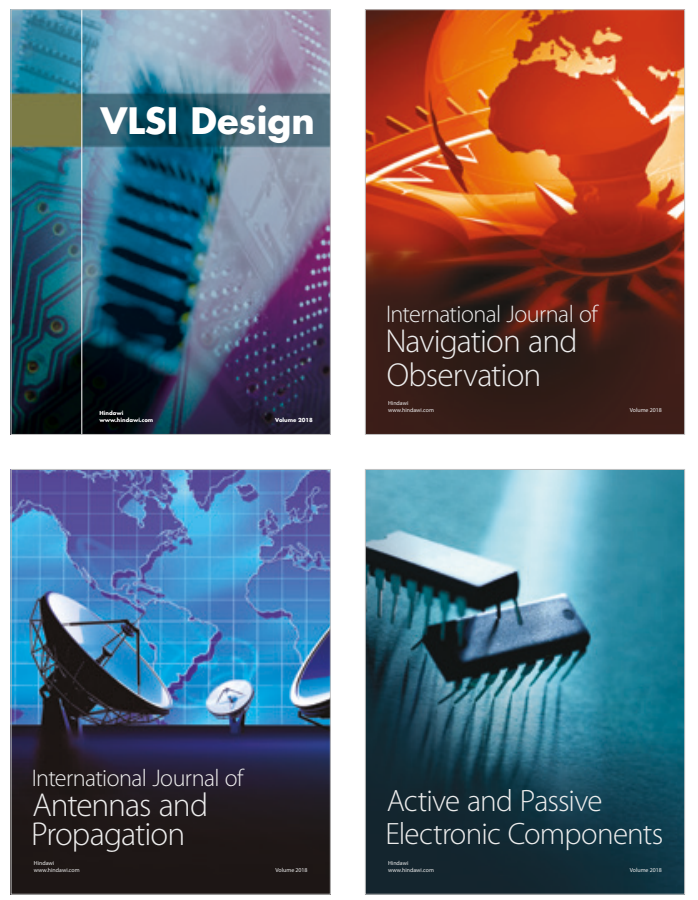
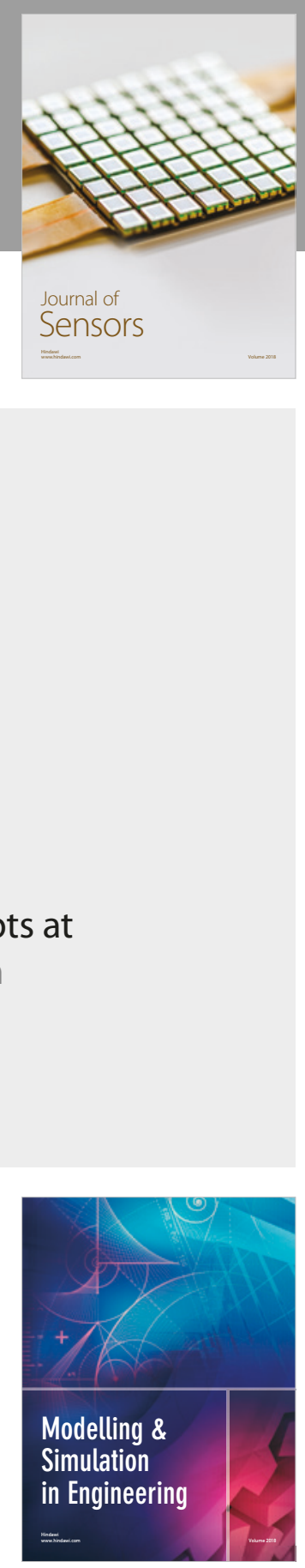

\section{Advances \\ Multimedia}
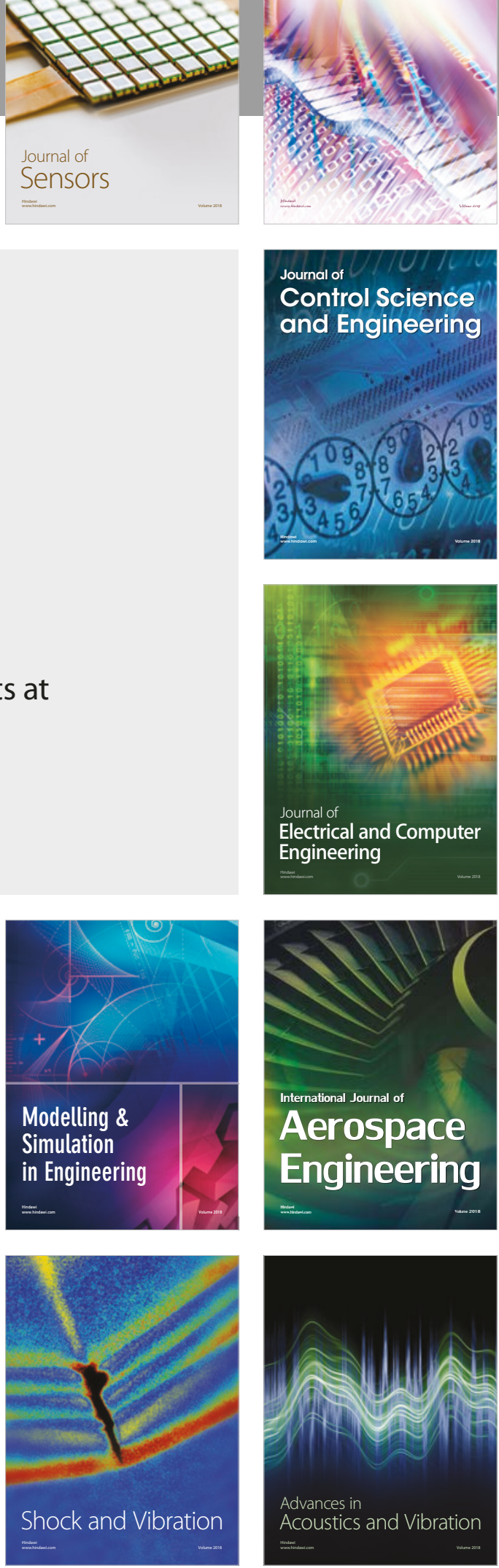